\title{
Peningkatkan Penetrasi Pengelasan pada Las TIG (Tungsten Inert Gas) Menggunakan Pengaruh Medan Elektromagnetik
}

\author{
Ario Sunar Baskoro', Tuparjonoํ, Erwanto', dan Winarto² \\ ${ }^{1}$ Departmen Teknik Mesin, Fakultas Teknik Universitas Indonesia, Depok \\ ${ }^{2}$ Departemen Teknik Metalurgi dan Material, Fakultas TeknikUniversitas Indonesia, Depok \\ E-mail: ario@eng.ui.ac.id
}

\begin{abstract}
ABSTRAK
Pengelasan Tungsten Inert Gas (TIG) adalah salah satu pengelasan yang memiliki kelebihan dari berbagai macam proses pengelasan yang membutuhkan kepresisian dan mutu yang baik. Pengelasan TIG banyak digunakan untuk pengelasan pelat tipis karena pembentukan busur yang kecil dan area yang dipanasi menjadi minimal sehingga mengurangi masalah penggunaan energi listrik dan distorsi pada pelat. Pada penelitian ini dilakukan percobaan dengan meletakkan solenoid magnetik di sekeliling obor las TIG. Pemanfaatan medan elektromagnetik ini dilakukan pada keadaan statis dan dinamis. Fenomena yang terbentuk akan diamati dengan menggunakan kamera sehingga diketahui pengaruh efek medan elektromagnetik bagi efiensi pengelasan pada saat pencairan logam las. Hasil dari penelitian menunjukkan pengaruh dari efek elektromagnetik pada pembentukan busur yang lebih stabil dan mengecil dengan penetrasi las yang dalam. Pengelasan ini juga menggunakan daya yang lebih rendah sehingga didapatkan efisiensi pemakaian energi listrik dan membatasi pemanasan yang lebih tinggi.
\end{abstract}

Kata kunci: Tungsten inert gas, stabilitas busur, penetrasi pengelasan, medan elektromagnetik.

\begin{abstract}
Tungten Inert Gas Welding (TIG) is a welding process that has advantages in precision and quality. TIG welding mostly used for welding thin plate because the formation of its arc is small and the heated area is minimized, so it can reduced power consumption and distortion of the plate. In this study, the solenoids were placed around the torch and conducted at static and dynamic condition. The arc phenomenon was observed using camera to identified the influenced of electromagnetic field to welding eficiency. The results showed that the influence of electromegnetic field has made the formation of arc became smaller with deeper penetration and more stable. This welding process also reduce the power consumption and heat.
\end{abstract}

Keyword: Tungsten Inert Gas, arc stability, welding penetration, lectromagnetic field

\section{PENDAHULUAN}

Pengelasan TIG (Tungsten Inert Gas) adalah sebuah proses pengelasan busur listrik yang menghasilkan gabungan logam oleh pemanasan sebuah busur listrik antara sebuah elektroda tungsten (nonconsumable) dan benda kerja. Area busur listrik akan dilindungi dari atmosfir oleh gas tidak aktif yang mengalir melalui nosel obor las. Beberapa keunggulan dari proses pengelasan TIG diantaranya adalah menghasilkan mutu pengelasan yang tinggi pada hampir semua logam dan logam paduan serta busur listrik serta kubang lasnya dapat dilihat secara jelas bagi juru las [1].

Elektromagnet adalah cara pembangkitan kemagnetan dengan menggunakan arus listrik.
Aplikasi praktisnya dapat ditemukan pada motor listrik, pengeras suara, relay dan sebagainya. Sebatang kawat yang diberikan listrik DC yang arahnya searah, maka di sekeliling kawat timbul garis gaya magnet yang melingkar.

Pemanfaatan efek elektromagnetik telah banyak diteliti pada bidang teknik, diantaranya untuk meningkatkan efisiensi pada pengelasan, salah satunya yaitu pada pengelasan TIG. Penelitian pendahuluan yang telah dilakukan oleh Yoshinori Hirata [2] menunjukkan bahwa manik las yang baik dapat terbentuk pada pengelasan TIG kecepatan tinggi yang dikontrol dengan magnetik [2]. Skema dari percobaan tersebut dapat ditunjukkan pada Gambar 1. 
Selain itu ada juga pengamatan efek magnetik pada kestabilan busur las [3]. Batasan efek magnetik yang dapat mempengaruhi kestabilan busur las juga dapat diketahui pada proses pengelasan [4]. Batasan efek magnetik tersebut dapat ditunjukkan pada Tabel 1.

Busur las yang terjadi pada pengelasan adalah proses yang sangat rumit dimana melibatkan fenomena seperti peralihan logam, busur temperatur tinggi dan cairan logam las. Pada pengelasan kecepatan tinggi dapat menurunkan kestabilan busur las sehingga mempunyai kecenderungan untuk menghasilkan cacat las. Gaya elektro magnetik berperan penting pada peristiwa gerakan cairan logam las sepanjang busur pengelasan tersebut. Pengontrolan magnetik merupakan solusi untuk mengantisipasi cacat tersebut karena mampu menghasilkan manik las yang baik. Penggunaan solenoid coil untuk membangkitkan medan magnet pada busur termagnetisasi berdampak pada penetrasi yang lebih dalam.

Dalam penelitian, solenoid magnetik diletakkan di sekeliling obor las TIG dengan kondisi statis dan dinamis. Efek dari penempatan ini akan dikontrol dan diinvestigasi untuk mengetahui kondisi kestabilan busur yangterjadi sehingga diketahui dampak pengunaan elektromagnetik tersebut pada efisiensi penggunaan daya listrik serta mutu pengelasan yang baik.

Tujuan penelitian ini untuk meningkatkan efisiensi daya listrik pada sistem pengelasan TIG dengan mendapatkan kestabilan busur yang lebih baik dengan penetrasi yang dalam dan daya yang lebih sedikit dibanding proses yang biasa untuk pengelasan pelat baja yang tipis.

\section{METODE PENELITIAN}

Skemasistem pengujian yang dilakukan ditunjukkan pada Gambar 2. Sistem terdiri dari penggerak dan pembawa obor las, kamera, sistem solenoid dan kontroler dan mesin las TIG. Sistem monitoring busur las dan posisi empat buah solenoid ditunjukkan pada Gambar 3 dan 4. Pengujian ini adalah merupakan pengelasan tanpa menggunakan bahan tambah (autogenous welding). Pengkondisian pengelasan ini tanpa pemanfaatan solenoid dan dengan pemanfaatan solenoid yang di pasang pada obor las (torch). Pemanfataan solenoid dapat dilakukan dengan 2 cara yaitu kondisi statis dan dinamis. Kondisi statis adalah kondisi dimana hanya satu solenoid yang aktif selama pengelasan. Sedangkan kondisi dinamis yaitu kondisi solenoid diaktifkan selama waktu tertentu dan aktif secara bergantian selama pengelasan. Pada pengujian dinamis dilakukan variasi pengaturan lamanya pengaktifan solenoid (delay) pada $50 \mathrm{~ms}, 150 \mathrm{~ms}$ dan $300 \mathrm{~ms}$. Untuk pengukuran yang akan dilakukan pada penelitian ini adalah dengan mengatur letak solenoid magnetik terhadap obor las serta ketinggiannya terhadap benda uji. Posisi obor las diam sedangkan posisi benda uji bergerak dengan arah gerakan menjauhi kamera sehingga proses terjadinya busur dan pencairan benda uji mudah diamati.

Tabel 2 menggambarkan parameter pengujian. Sedangkan Tabel 3 menunjukkan pengaturan arus, kecepatan pengelasan dan pengkondisian solenoid magnetic. Benda uji yang digunakan adalah pelat baja karbon dengan ketebalan $2 \mathrm{~mm}$, lebar $50 \mathrm{~mm}$ dan panjang $100 \mathrm{~mm}$ sebanyak 10 buah. Pengelasan dilakukan dengan menggunakan tipe arus DC, polaritas elektroda negatif (EN) dan diameter elektroda 2,4 mm.

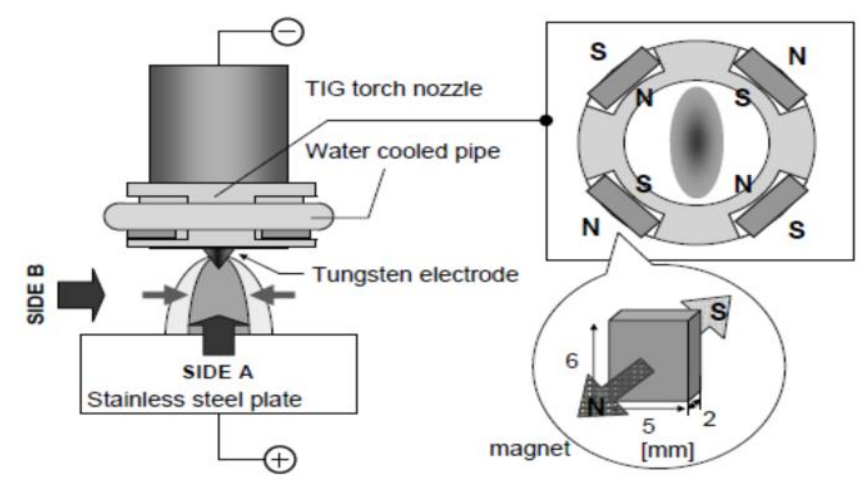

Gambar 1. Susunan Percobaan [1]

Tabel 1. Batasan Efek Magnetik pada Proses Las [4]

\begin{tabular}{ccccc}
\hline Welding process & 0-10 Gauss & 10-20 Gauss & 20-40 Gauss & Over 40 Gauss \\
\hline TIG & Normal Welding & Arc Instability & Arc Blow & Serve Arc Blow \\
Manual Metal Arc & Normal Welding & Normal & Arc Instability & Arc Blow \\
Submerged Arc & Normal Welding & Normal & Normal & Arc Instability \\
\hline
\end{tabular}




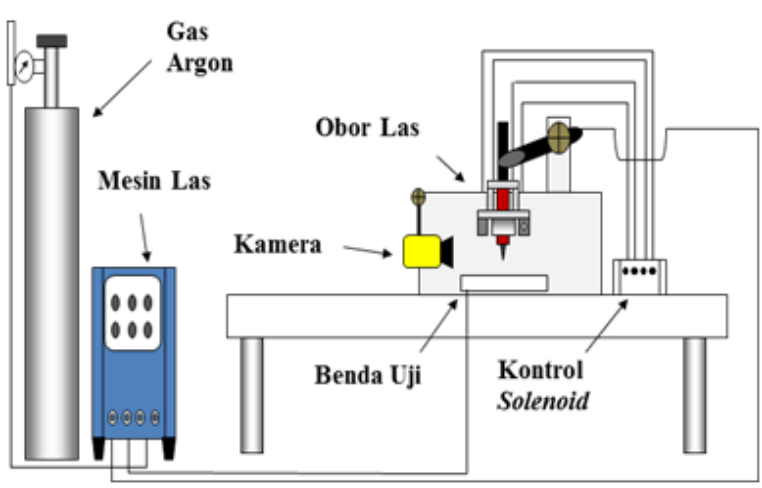

Gambar 2. Skema SistemPengujian

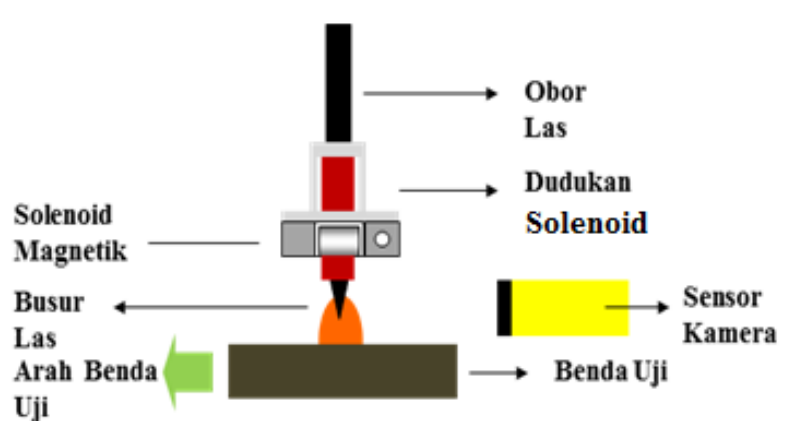

Gambar 3. Skema Monitoring Busur

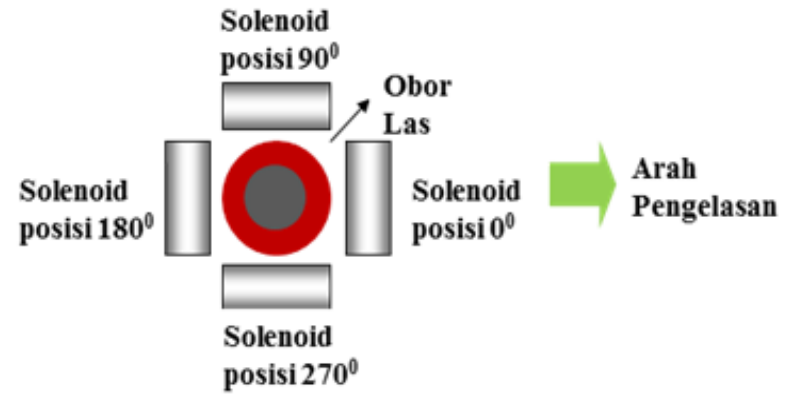

Gambar 4. Susunan Solenoid

Tabel 2. Parameter Pengujian

\begin{tabular}{ll}
\hline Mesin Las & DCEN \\
\hline Elektroda Tungsten & $\begin{array}{l}\text { EWP (Diameter 2,4 mm atau } \\
\text { 3/32 in) }\end{array}$ \\
Benda uji & $\begin{array}{l}\text { Plat baja karbon dan stainless } \\
\text { steel } \mathrm{SS} 304, \text { Dimensi : } 2 \mathrm{~mm} \times 50 \\
\mathrm{~mm} \times 100 \mathrm{~mm}\end{array}$ \\
& 1 set \\
Dudukan Solenoid & $70-95 \mathrm{~A}$ \\
Arus busur & Argon $100 \%$ \\
Gas Pelindung & $3-5 \mathrm{l} / \mathrm{min}$ \\
Kecepatan Aliran Gas & \\
Argon & $1-2 \mathrm{~mm} / \mathrm{s}$ \\
Kecepatan Pengelasan & \\
= 1,03 mm/s, Aliran Gas & \\
Argon = 3 l/min, Tanpa & \\
Solenoid & \\
Kecepatan Pengelasan & \\
SolenoidMagnetik & 4 pcs $(\mathrm{I}=0,15 \mathrm{~A}, \mathrm{~V}=5 \mathrm{~V}, \mu=4 \Pi$ \\
& $\left.10^{-7} \mathrm{~T} / \mathrm{Amp} \mathrm{M}\right)$ \\
\hline
\end{tabular}

Tabel 3. Variasi Pengujian

\begin{tabular}{|c|c|c|c|c|}
\hline $\begin{array}{l}\text { Arus Las } \\
\text { (A) }\end{array}$ & $\begin{array}{c}\text { Kecepatan } \\
\text { Pengelasan } \\
(\mathrm{mm} / \mathrm{s})\end{array}$ & $\begin{array}{c}\text { Aliran Gas } \\
\text { Argon } \\
\text { (1/min) }\end{array}$ & $\begin{array}{c}\text { Panjang } \\
\text { Las } \\
\text { (mm) }\end{array}$ & Kondisi \\
\hline 70 & 1,03 & 3 & 90 & $\begin{array}{c}\text { Tanpa } \\
\text { Solenoid }\end{array}$ \\
\hline 80 & 1,03 & 3 & 90 & $\begin{array}{l}\text { Tanpa } \\
\text { Solenoid }\end{array}$ \\
\hline 95 & 1,03 & 3 & 90 & $\begin{array}{c}\text { Tanpa } \\
\text { Solenoid }\end{array}$ \\
\hline 70 & 1,5 & 3 & 90 & $\begin{array}{l}\text { Tanpa } \\
\text { Solenoid }\end{array}$ \\
\hline 80 & 1,5 & 3 & 90 & $\begin{array}{c}\text { Tanpa } \\
\text { Solenoid }\end{array}$ \\
\hline 95 & 1,5 & 3 & 90 & $\begin{array}{c}\text { Tanpa } \\
\text { Solenoid }\end{array}$ \\
\hline 70 & 1,5 & 3 & 90 & Ada Solenoid \\
\hline 70 & 1,5 & 3 & 90 & Ada Solenoid \\
\hline 70 & 1,5 & 3 & 90 & Ada Solenoid \\
\hline 70 & 1,5 & 3 & 90 & Ada Solenoid \\
\hline
\end{tabular}

\section{HASIL DAN PEMBAHASAN}

\section{Perhitungan Medan}

Untuk menghitung besar medan elektromagnetik yang ditimbulkan dari solenoid, maka dapat menggunakan persamaan umum medan elektromagnetik yaitu: $\mathrm{B}=\mu_{0} \mathrm{n}$ I.Solenoid yang digunakan memiliki permeabilitas $\left(\mu_{0}\right)=4 \Pi \times 10^{-7} \mathrm{~T} / \mathrm{Amp} \mathrm{M}$, arus $=0,15 \mathrm{~A}$, panjang solenoid $20 \mathrm{~mm}$, diameter kawat solenoid $=0,5 \mathrm{~mm}$. Dari data tersebut didapat medan elektromagnetik (B) yang terjadi sebesar 3,77 $\mathrm{x} 10^{-4}$ Tesla atau 3,77 Gauss

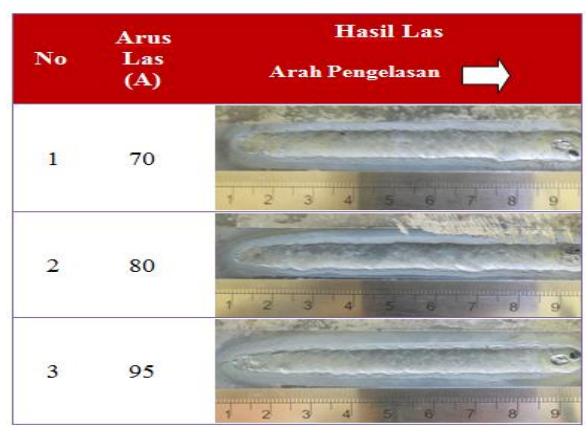

(a) Kecepatan Pengelasan $=1,03 \mathrm{~mm} / \mathrm{s}$, Aliran Gas Argon $=3 \mathrm{l} / \mathrm{min}$, Tanpa Solenoid

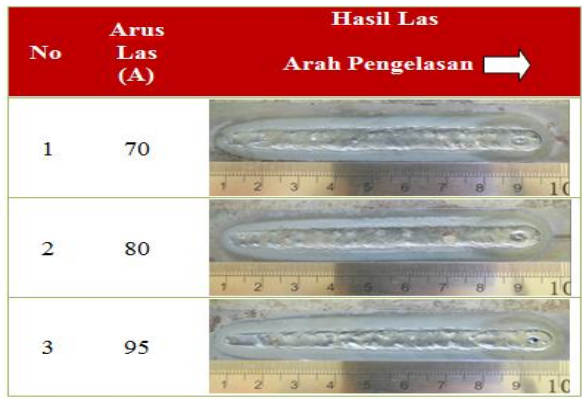

(b) Kecepatan Pengelasan $=1,5 \mathrm{~mm} / \mathrm{s}$, Aliran Gas Argon $=$ 3 1/min, Tanpa Solenoid

Gambar 5. Hasil Pengujian pada Plat Baja Karbon dengan Perbedaan Kecepatan 


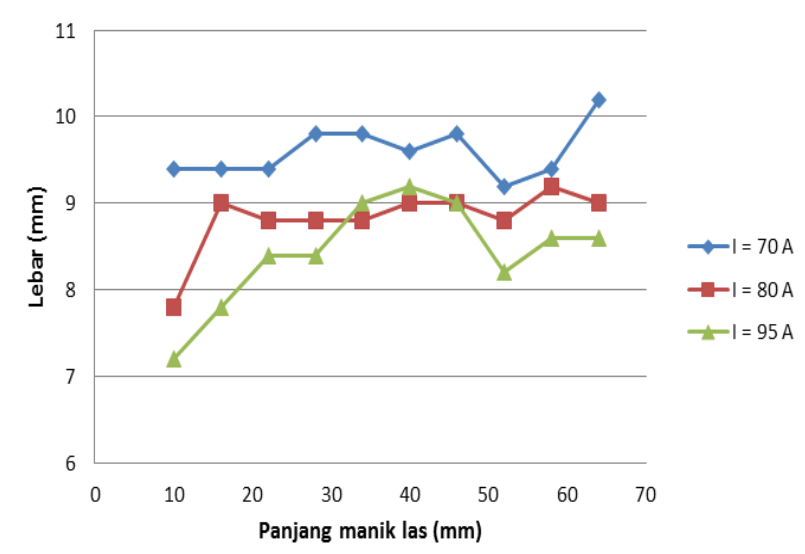

(a) Kecepatan Pengelasan $=1,03 \mathrm{~mm} / \mathrm{s}$, Aliran Gas Argon $=3 \mathrm{l} / \mathrm{min}$, Tanpa Solenoid

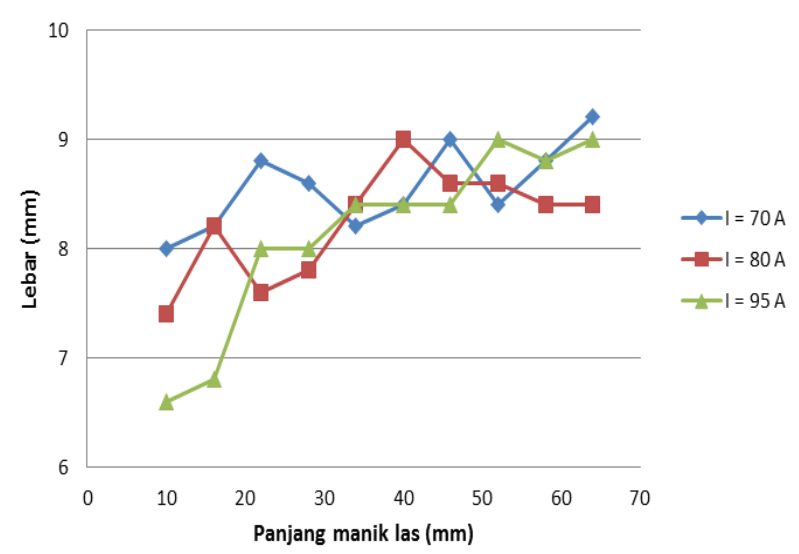

(b) Kecepatan Pengelasan = 1,5 mm/s, Aliran Gas Argon = $3 \mathrm{l} / \mathrm{min}$, Tanpa Solenoid

Gambar 6. Lebar Lasan Plat Baja Karbon dengan Kecepatan Pengelasan yang Berbeda

\section{Pengujian dengan Perbedaan Kecepatan}

Pada kecepatan pengelasan yang sama yaitu sebesar $1,03 \mathrm{~mm} / \mathrm{s}$ dan pada arus las yang berbeda yaitu pada 70, 80 dan 95 Amper, lebar lasan yang terjadi sama besar yaitu berkisar pada $8 \mathrm{~mm}$. Sedangkan pada kecepatan pengelasan sebesar 1,5 $\mathrm{mm} / \mathrm{s}$, lebar lasannya berkisar $7 \mathrm{~mm}$. Untuk mengetahui perbedaan lebar lasan yang terjadi dapat dilihat pada Gambar 5a dan b serta Gambar 6. Untuk hasil pengujian tanpa solenoid dan dengan solenoid aktif dalam posisi statis dan dinamis ditunjukkan dalam Gambar 7 a, b dan c. Sedangkan hasil lebar manik las ditunjukkan pada Gambar 8, a dan b. Gambar 9 menunjukkan lebar hasil manik las menggunakan solenoid dalam kondisi dinamis dan variasi waktu delay.

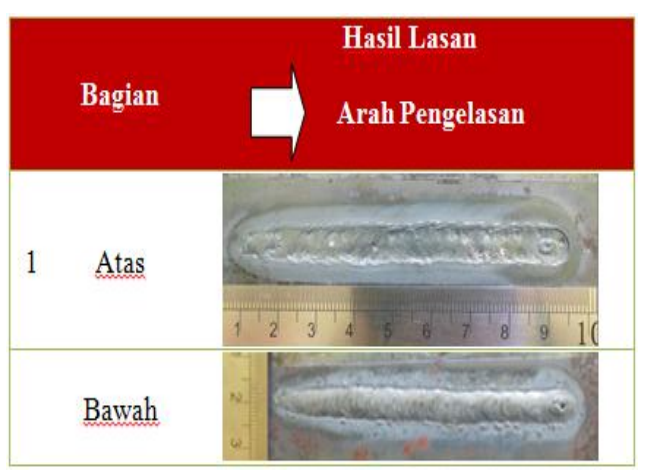

a. Arus $=70 \mathrm{~A}$, Kecepatan Pengelasan $=1,5 \mathrm{~mm} / \mathrm{s}$, Aliran Gas Argon $=31 / \mathrm{min}$, Tanpa Solenoid

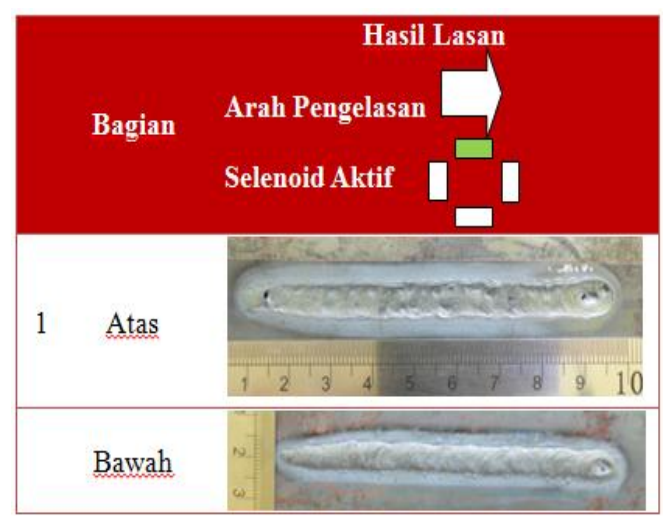

b. Arus $=70$ A, Kecepatan Pengelasan $=1,5 \mathrm{~mm} / \mathrm{s}$, Aliran Gas Argon $=3 \mathrm{l} / \mathrm{min}$, Ada SolenoidPosisi $90^{\circ}$, Kondisi Statis

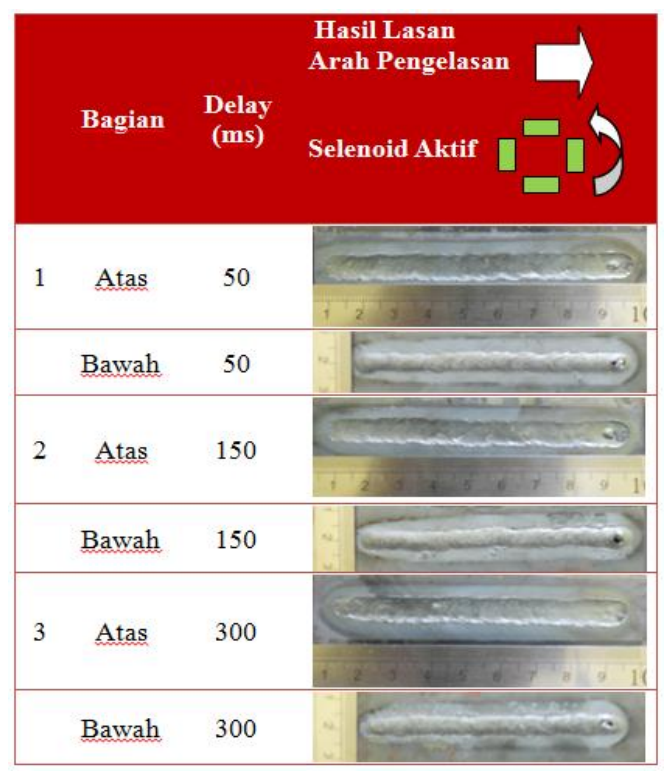

c. Kecepatan Pengelasan = 1,5 mm/s, Aliran Gas Argon = $3 \mathrm{l} / \mathrm{min}$, Arus $=70 \mathrm{~A}$, Ada Solenoid, Kondisi Dinamis.

Gambar 7. Hasil Pengujian pada Plat Baja Karbon Tanpa Solenoid, dengan Solenoid Statis dan Dinamis 


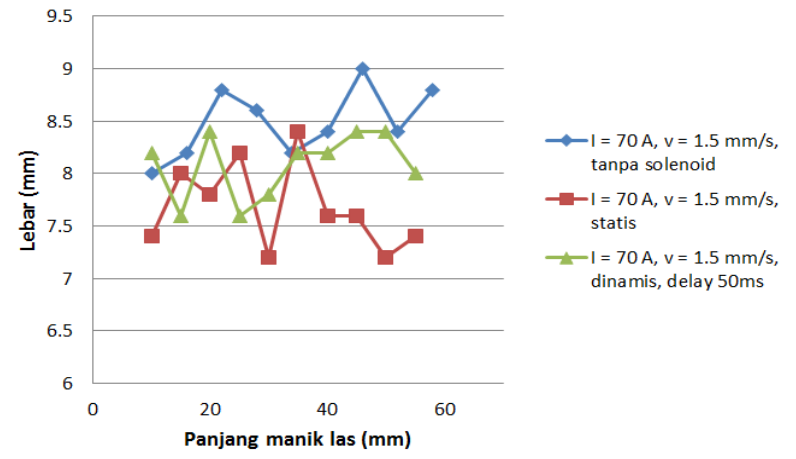

a. Lebar Manik Las Bagian Atas

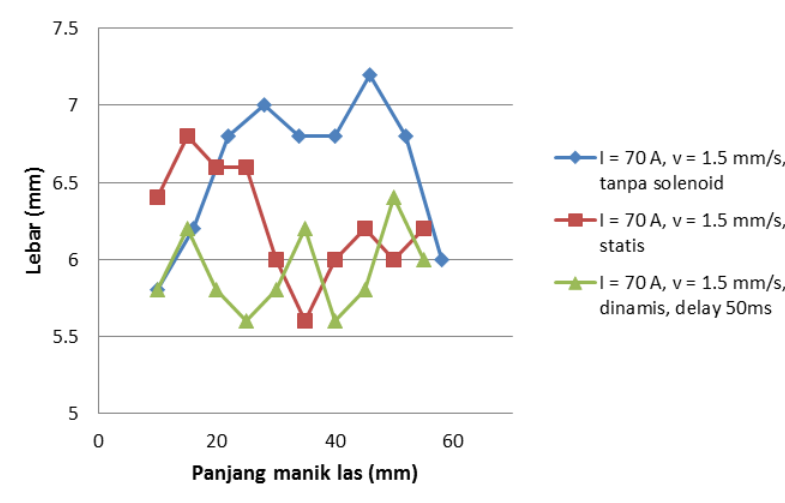

b. Lebar Manik Las Bagian Bawah

Gambar 8. Lebar Manik Las Plat Baja Karbon Tanpa dan dengan Solenoid

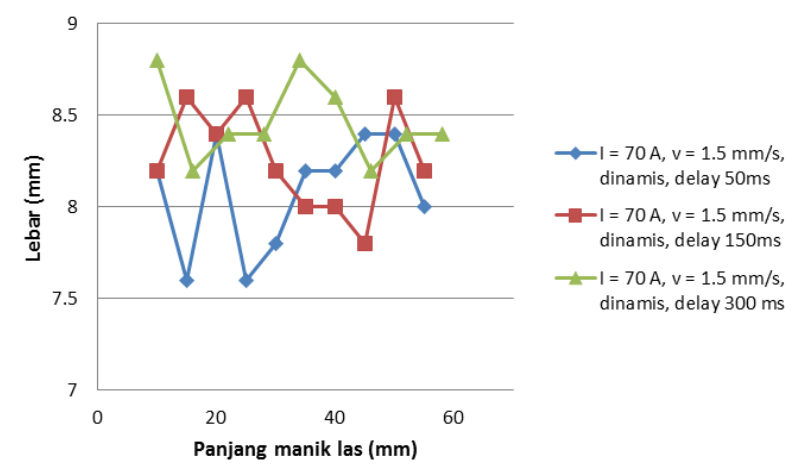

a. Lebar Manik Las Bagian Atas

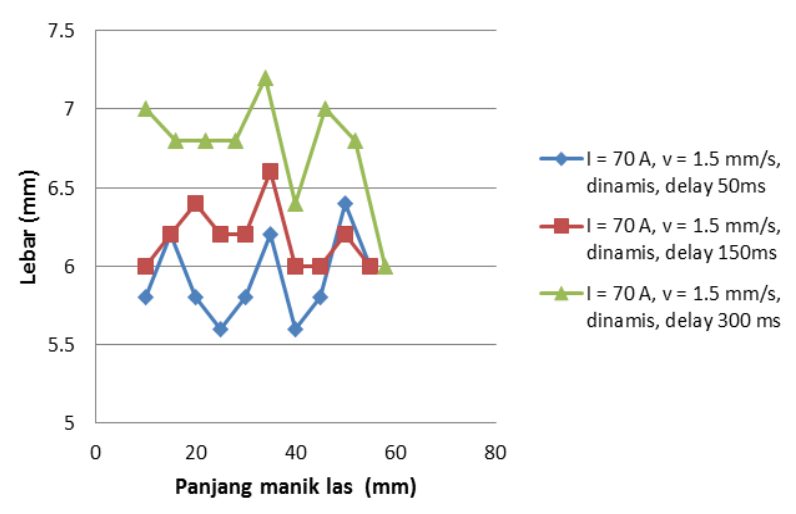

b. Lebar Manik Las Bagian Bawah

Gambar 9. Lebar Manik Las Pelat Baja Karbon Menggunakan Solenoid dan Variasi Waktu Delay
Fenomena yang terjadi pada busur las pada saat pengelasan dengan arus $70 \mathrm{~A}$, kecepatan 1,5 $\mathrm{mm} / \mathrm{s}$ dan aliran gas argon 3 liter/min dan tanpa solenoid mengalami perubahan jika dibandingkan dengan kondisi statis maupun dinamis. Fenomena tersebut dapat dilihat pada Gambar 10

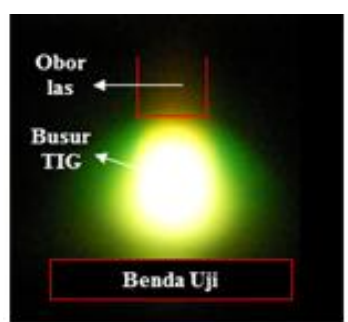

(a) Tanpa solenoid

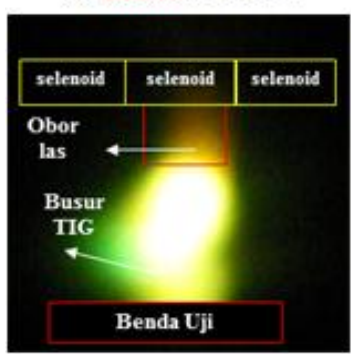

(c) Dinamis delay $50 \mathrm{~ms}$

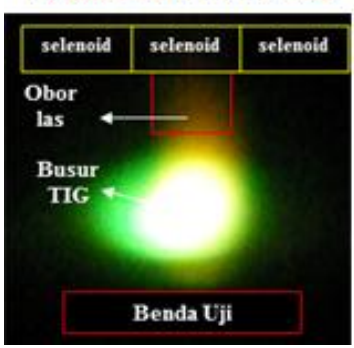

Gambar 10. Fenomena Busur Las

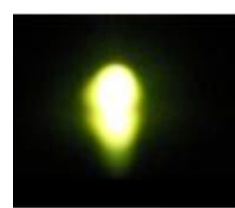

(a) $\mathrm{T}=1 \mathrm{~s}$

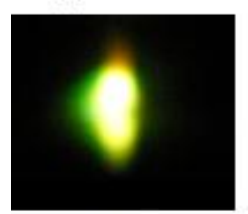

(d) $\mathrm{T}=15 \mathrm{~s}$

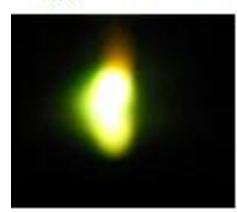

(g) $\mathrm{T}=25 \mathrm{~s}$

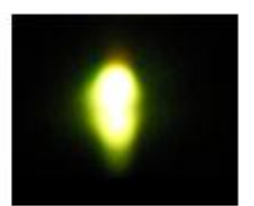

(b) $\mathrm{T}=5 \mathrm{~s}$

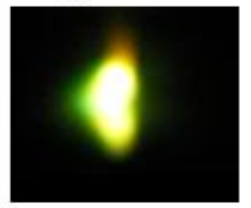

(e) $\mathrm{T}=20 \mathrm{~s}$

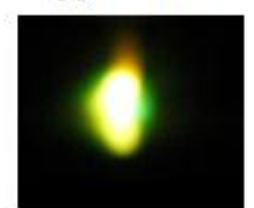

(h) $\mathrm{T}=27 \mathrm{~s}$

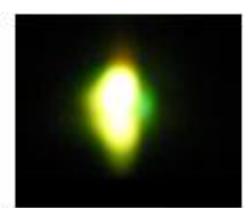

(c) $\mathrm{T}=10 \mathrm{~s}$

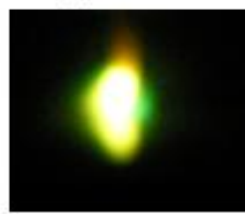

(f) $\mathrm{T}=23 \mathrm{~s}$

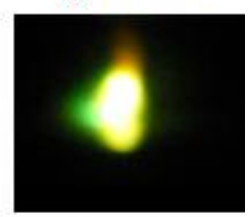

(i) $\mathrm{T}=36 \mathrm{~s}$
Gambar 11. Fenomena Busur Las pada Solenoid Dinamis 


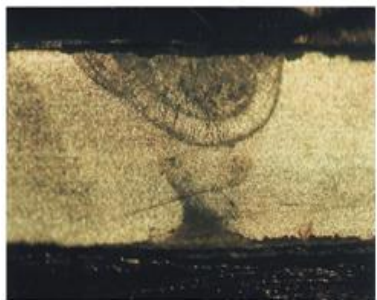

(a) $\mathrm{I}=90 \mathrm{~A}, \mathrm{v}=1.5 \mathrm{~mm} / \mathrm{s}$

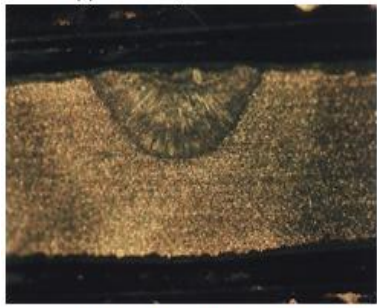

(c) I $=85 \mathrm{~A}, \mathrm{v}=1.5 \mathrm{~mm} / \mathrm{s}$, delay $150 \mathrm{~ms}$

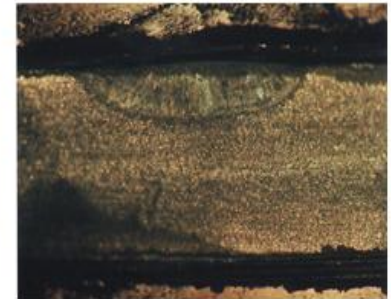

(b) $\mathrm{I}=85 \mathrm{~A}, \mathrm{v}=1.5 \mathrm{~mm} / \mathrm{s}$, delay $50 \mathrm{~ms}$

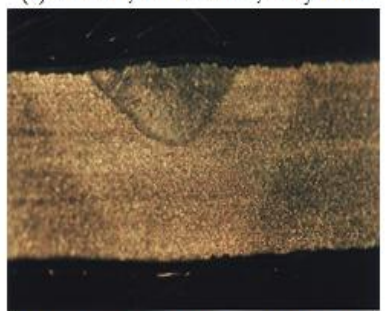

(d) $\mathrm{I}=85 \mathrm{~A}, \mathrm{v}=1.5 \mathrm{~mm} / \mathrm{s}$, delay $300 \mathrm{~ms}$

Gambar 12. Penetrasi Pengelasan pada Material Stainless Steel SS304

Pengamatanterhadap busur las yang dipengaruhi medan elektromagnetik pada kondisi dinamis juga dilakukan pada waktu tertentu dengan delay $150 \mathrm{~ms}$. Hasil pengamatan tersebut ditunjukkan pada Gambar 11.

Dampak medan elektromagnetik yang terjadi pada busur las sebesar 3,77 Gauss telah memenuhi kategori normal untuk kestabilan busur las. Hal ini mengacu pada batasan efek magnetik untuk kestabilan normal busur las TIG yaitu 0-10 Gauss (sesuai Tabel 1). Dalam pengujian terlihat bahwa fenomena medan elektromagnetik yang berputar ketika mempengaruhi busur las ternyata dapat membentuk pola gerakan seperti gerakan ayunan pada pengelasan. Hal ini juga yang menjadi alasan bahwa hasil lasan pada top bead lebih halus seperti yang dijumpai pada hasil lasan pada arus las yang sama tetapi kecepatan pengelasannya lebih lambat yaitu $1,03 \mathrm{~mm} / \mathrm{s}$ atau pada arus las hingga $95 \mathrm{~A}$.

Dengan mengamati hasil pengujian pada variasi arus dan kecepatan selama pengelasan serta membandingkan beberapa kondisi pengujian baik tanpa dipengaruhi medan elektromagnetik dan dengan medan elektromagnetik menunjukkan adanya keunggulan pada pemanfaatan medan elektromagnetik. Pada kasus ini terbukti bahwa pada kondisi normal, hasil lasan yang seharusnya dilakukan pada arus pengelasan yang lebih tinggi yaitu pada $95 \mathrm{~A}$ atau pada kecepatan pengelasan yang lebih lambat pada $1,03 \mathrm{~mm} / \mathrm{s}$ dapat dilakukan dengan pengelasan yang lebih cepat yaitu $1,5 \mathrm{~mm} / \mathrm{s}$ dan arus yang lebih rendah yaitu 70 A dengan memanfaatkan medan elektomagnetik.

Dari perhitungan input kalor (heat input) untuk arus $95 \mathrm{~A}$ pada kecepatan pengelasan 1,03 $\mathrm{mm} / \mathrm{s}$ dihasilkan 1,2 kJ/mm. Pada arus $95 \mathrm{~A}$, kecepatan pengelasan $1,5 \mathrm{~mm} / \mathrm{s}$ dihasilkan 1,6 $\mathrm{kJ} / \mathrm{mm}$ dan pada arus $70 \mathrm{~A}$, kecepatan pengelasan

$1,5 \mathrm{~mm} / \mathrm{s}$ dengan memanfaatkan medan elektomagnetik dihasilkan $0,84 \mathrm{~kJ} / \mathrm{mm}$. Hal ini membuktikan bahwa telah terjadinya penurunan pada heat input pada proses pengelasan sebesar 0,76 kJ/mm sehingga telah terjadi efisiensi dalam penggunaan daya listrik.

Pada Gambar 12 ditunjukkan hasil foto makro dari penetrasi pengelasan pada material stainless steel SS304 dengan tanpa dan dengan menggunakan solenoid. Gambar 10a menunjukkan pengelasan pada arus $\mathrm{I}=90 \mathrm{~A}$ dan kecepatan $\mathrm{v}=1,5 \mathrm{~mm} / \mathrm{s}$. Arus yang dibutuhkan untuk pengelasan lebih besar bila dibandingkan pada pengelasan baja karbon. Gambar 10 b dan 10 d ditunjukkan hasil pengelasan menggunakan solenoid menggunakan arus $\mathrm{I}=85 \mathrm{~A}$ dan kondisi dinamis dengan delay yang digunakan adalah 50, 150 dan $300 \mathrm{~ms}$. Terlihat bahwa pada pengelasan dengan arus yang lebih rendah dan delay $50 \mathrm{~ms}$, penetrasi masih belum terlalu dalam. Pada arus I = 85 A dan delay $150 \mathrm{~ms}$, hasil kedalaman penetrasi las yang dihasilkan sama dengan pengelasan menggunakan arus $\mathrm{I}=90 \mathrm{~A}$, seperti ditunjukkan pada Gambar 12c Sedangkan pada arus $\mathrm{I}=85 \mathrm{~A}$ dan delay $300 \mathrm{~ms}$ (Gambar 12d), hasil kedalaman penetrasi las sedikit berkurang dan lebar pengelasan agak lebih sempit bila dibandingkan dengan delay $150 \mathrm{~ms}$. Oleh karena itu, dari percobaan ini didapatkan bahwa terdapat peningkatan penetrasi pengelasan menggunakan pengaruh medan elektromagnetik sehingga terjadi efisiensi dalam penggunaan daya listrik dan membatasi pemanasan yang lebih tinggi.

\section{KESIMPULAN}

Fenomena kestabilan busur las dapat terganggu oleh pengaruh medan elektromagnet dengan waktu yang lama dan kondisi statis. Kestabilan busur las yang terjadi akibat adanya dampak medan elektromagnetik masih dalam batasan normal yaitu 3,77 Gauss.

Pengaruh medan elektromagnetik pada kondisi dinamis menghasilkan lebar lasan lebih kecil dan penetrasi yang dalam jika dibandingkan dengan kondisi normal. Input kalor yang terjadi pada hasil pengelasan yang dipengaruhi oleh medan elektromagnetik lebih rendah jika dibandingkan dengan tanpa medan elektromagnetik sehingga telah terjadi efisiensi dalam penggunaan daya listrik. Penetrasi pengelasan pada material stainless steel SS304 dengan menggunakan pengaruh medan elektromagnetik untuk arus $\mathrm{I}=85 \mathrm{~A}$ dan delay $150 \mathrm{~ms}$ memiliki hasil yang sama dengan pengelasan menggunakan arus pengelasan yang lebih tinggi yaitu I = $90 \mathrm{~A}$, sehingga telah terjadi efisiensi dalam penggunaan daya listrik dan membatasi pemanasan yang lebih tinggi. 


\section{DAFTAR PUSTAKA}

[1] Howard, B. dan Carry, Modern Welding Technology, second edition, Prentice-Hall, New Jersey, 1989.

[2] Hirata, Y., Nomura, K., dan Morisaki, K., Magnetic control of TIG arc plasma, ASM International, 2009.
[3] Y. Suga, The effect magnetic field on stabilization of TIG arc welding under hyperbaric helium atmosphere, The International Society of Offshore and Polar Engineers, Vol. IV, 1991.

[4] Deverse Technologies, Magnetic effect on the welding process, Cambridge, http://website.lineone. net/ diverse/layer2/zeropr.htm, 30 July 2012. 